\title{
EFFECT OF HEALTH LECTURE USING MEDIA AND PEER-EDUCATION ON LONG ACTING AND PERMANENT METHODS OF CONTRACEPTION
}

\author{
Helen Ermalia1, Jimmy Yanuar Annas2, Samsriyaningsih Handayani3 \\ 1 Midwifery Education Program Study, Faculty of Medicine, Universitas Airlangga, Surabaya, Indonesia \\ 2 Department of Obstetrics and Gynecology, Faculty of Medicine, Universitas Airlangga, Surabaya Indonesia \\ 3 Department of Public Health and Preventive Medicine, Faculty of Medicine, Universitas Airlangga, Surabaya \\ Indonesia
}

\begin{abstract}
Introduction: Long-acting and permanent methods of contraception (LAPMs) are known as highly-effective contraception. The Department of Health of East Java Province stated that LAPM participation is still below target. One of the factors is the Interpersonal Communication (IPC) skill of the Health Practitioners. This study aimed to identify the influence of health lectures using media and peer-education on the knowledge and attitude of pregnant women regarding LAPMs. Peer-education is the novelty of this study.
\end{abstract}

Methods: A two-group quasi experimental design was applied with all of the pregnant women at Kesugihan Public Health Center (PHC) as the treatment group. They were given lectures with media inclusion (contraception booklets and visual aids) and peer-education during a pregnancy class. Pregnant women at Ngebel PHC were the control group. One woman who had experience with LAMPs was trained as a peer-educator. Thirty participants in each group were chosen using the total sampling technique. The data collected was analyzed using univariate and bivariate analyses by applying the Wilcoxon Signed-Rank and Mann-Whitney tests.

Results: The participants showed an increased knowledge before and after the intervention in the treatment group (83\%), while in control group, it was slightly increased (1\%). Attitude differences were also found in both groups (treatment $=56.7 \%$, control $=13.3 \%$ ). The Mann-Whitney test resulted in significant differences on knowledge $(p<0.001)$ and attitude $(p=0.016)$ between the two groups.

Conclusion: The local department of health may optimize IPC using media and peer-education to improve the knowledge and attitude of pregnant women regarding LAPM participation.

\section{ARTICLE HISTORY}

Received: August 12, 2018

Accepted: November 27, 2019

\section{KEYWORDS}

Long-acting and Permanent Methods of Contraception (LAPMs); knowledge of LAPMs; attitude about LAPMs; media; peereducation.

\section{CONTACT}

Samsriyanigsih Handayani $\triangle$ samsri.handayani@gmail.com $\ggg$ Faculty of Medicine, Universitas Airlangga, Surabaya, Indonesia

Cite this as: Ermalia, H. (2019). Effect of Health Lecture Using Media and Peer-Education On Long Acting and Permanent Methods of Contraception. Jurnal Ners, 14(1), 92-96. doi:http://dx.doi.org/10.20473/jn.v13i2.9373

\section{INTRODUCTION}

Long acting and permanent methods of contraception (LAPMs) are known to be highly effective (Kemenkes, RI, 2013), with a low rate of failure and more benefits compared to other methods of contraception (Hartanto, 2010). LAPMs are contraception methods that can be used from 3 years up until a lifetime. These include intrauterine devices, hormonal implants, female sterilization and vasectomies (Affandi, 2012). The Department of Health of East Java Province revealed that LAPM participation is still below target. The data shows that only $22.4 \%$ of women use LAPMs from $5,576,723$ as the total number of active contraceptive users.

LAPMs are promoted by the government as an effort to lower the rate of population growth (BKKBN, 2016). The improper treatment of population growth will result in a population 
explosion which can leads to a negative impact on the demography. Several issues that have impacted on the negative side of demography bonuses are less jobs for citizens, unemployment problems, a low education rate, severe social effects and a loss of momentum when it comes to money-saving, leading to extreme poverty (Kominfo, 2014). Health problems will also emerge, specifically for mothers and children (Kemenkes RI, 2016). The increase in LAPM participation can be the solution to preventing further problems. Despite this fact, many factors are involved in LAPM participation such as culture, society, the economy, educational background, health facilities and Family Planning Programs. This is in addition to health practitioner-related issues (Shodiq, 2016).

The role of health practitioners is essential especially during health education and interpersonal communication (HIC) related to LAPM participation (Hartanto, 2010). Media presence and interactive messages can affect health education (Notoatmodjo, 2010), contributing to the success rate of contraceptive use (Hartanto, 2010). Most of the HIC conducted by health practitioners is interpersonal counseling focused on the contraception candidate acceptor (Kemenkes RI, 2014). In this study, using peer-education as a novel method to introduce contraception, we sought to determine the importance of proper health education. This research thus aimed to analyze the influence of media usage and peer-education on the knowledge and attitude of pregnant women related to LAPM participation.

\section{MATERIALS AND METHODS}

The locations of this research study were 2 pregnancy classes in Kesugihan Public Health Center (PHC) and Ngebel Public Health Center, Ponorogo region. The research design for this study was quasiexperimental with a non-randomized control group pretest-posttest. The population of this study was all of the pregnant mothers in Kesugihan PHC as the treatment group and those in Ngebel PHC became the control group. The study variables were knowledge and attitude toward LAPMs among pregnant women. A total of 30 participants for each group were calculated using the Federer formula and they were chosen using non-probability sampling as the total sampling technique. All of the pregnant women were chosen as the sample based on the selected inclusion criteria i.e. registered to a pregnancy class, spoke Bahasa Indonesia and they had graduated from middle school. Pregnant mothers with a pathological history and who had experienced an obstetric emergency were excluded from the study. The intervention applied consisted of a 45-minute lecture, media (booklet) distribution that had previously been tested for its clarity and a 45-minute session of peer-education by a trained woman who had experience with LAPMs. The media (booklet) was written by the National Family Planning Board (BKKBN) and it was tested for clarity. Some modifications to the booklet were applied following the test results. The peer-educator was trained to share her experience guided by a list of topics. The intervention ended with a discussion. The data was collected by giving pre- and post-tests for both groups during a pregnancy class. The posttest was conducted at the end of the session. The pre- and post-tests were conducted on the same day without a recess. The questions in the pre- and posttests were tested for reliability and validity. The overall Cronbach's alpha for the 8 questions on knowledge were 0.644 and the coefficient for the 8 questions on attitude was 0.958 . The validity test using the Pearson product moment correlation revealed coefficients from 0.376 to 0.612 for the 8 questions on knowledge and 0.725 to 0.981 was found for the 8 questions on attitude. The data was analyzed using univariate and bivariate analyses. The Wilcoxon signed-rank test was used to analyze the difference in knowledge levels and the attitude before and after treatment in each group. The Mann Whitney test was conducted to analyze the difference in their increased knowledge and the altered attitudes between the groups. Ethical clearance was obtained from the Ethical Committee on Health Research of the Medical Faculty of Universitas Airlangga number331/EC/KEPK/FKUA/2017 and the Badan Kesatuan Bangsadan Politik of Ponorogo District number 0721/01/405.30/2017.

\section{RESULTS}

The participants' Characteristics within the Control and Intervention Groups are as shown in Table 1. Table 1 showed that the respondents from both groups had similar characteristics. The knowledge and Attitude Scores of the Control and Intervention Groups are as shown in Table 2.

The Wilcoxon signed-rank test resulted in a $\mathrm{p}$ of $0.00 \quad(p<0.01)$ showing a significant knowledge difference before and after the intervention in the treatment group. The Wilcoxon signed-rank test resulted in a p of $0.317(p>0.05)$ for the control group, thus showing no difference between the pretest and post-test. The Wilcoxon signed-rank test resulted in a $\mathrm{p}$ of $0.000(\mathrm{p}<0.05)$, indicating a significant attitude difference in the treatment group before and after the intervention and a $p=0.102$ ( $p>0.05)$, suggesting no attitude difference in the control group. 
Table 1. Participants' Characteristics in the Control and Intervention Groups

\begin{tabular}{|c|c|c|c|c|c|c|c|c|}
\hline \multirow{2}{*}{ Variable } & & \multicolumn{2}{|c|}{ Control Group } & \multicolumn{2}{|c|}{ Treatment Group } & \multicolumn{2}{|c|}{$\mathbf{n}$} & \multirow[b]{2}{*}{$p$} \\
\hline & & $\mathbf{n}$ & $\%$ & $\mathbf{n}$ & $\%$ & $\mathbf{n}$ & $\%$ & \\
\hline \multicolumn{9}{|l|}{ Age } \\
\hline 20-30 years-old & & 19 & 63.3 & 16 & 53.3 & 35 & 58.3 & \multirow[t]{3}{*}{0.510} \\
\hline \multirow[t]{2}{*}{ 31-40 years-old } & & 11 & 36.7 & 14 & 26.7 & 25 & 41.7 & \\
\hline & Total & & & & & 60 & 100 & \\
\hline \multicolumn{9}{|l|}{ Education } \\
\hline Middle School & & 14 & 46.7 & 13 & 43.3 & 27 & 45 & \multirow{3}{*}{0.417} \\
\hline High School & & 13 & 43.3 & 13 & 43.3 & 26 & 43.3 & \\
\hline \multirow[t]{2}{*}{ College } & & 3 & 10 & 4 & 13.4 & 7 & 11.7 & \\
\hline & Total & & & & & 60 & 100 & \\
\hline \multicolumn{9}{|l|}{ Occupation } \\
\hline Unemployed & & 16 & 53.3 & 22 & 73.3 & 38 & 63.3 & \multirow{2}{*}{0.825} \\
\hline \multirow[t]{2}{*}{ Employed } & & 14 & 46.7 & 8 & 26.7 & 22 & 36.7 & \\
\hline & Total & & & & & 60 & 100 & \\
\hline \multicolumn{9}{|l|}{ Gravida } \\
\hline Primigravida & & 5 & 16.7 & 6 & 20 & 11 & 18.3 & \multirow[t]{2}{*}{0.221} \\
\hline \multirow[t]{2}{*}{ Multigravida } & & 25 & 83.3 & 24 & 80 & 49 & 81.7 & \\
\hline & Total & & & & & 60 & 100 & \\
\hline \multicolumn{9}{|l|}{ Child alive } \\
\hline Nullipara & & 7 & 23.3 & 8 & 26.7 & 15 & 25 & \multirow{3}{*}{0.266} \\
\hline 1 child & & 18 & 60 & 16 & 53.3 & 34 & 56.7 & \\
\hline \multirow[t]{2}{*}{2 children } & & 5 & 16.7 & 6 & 20 & 11 & 18.3 & \\
\hline & Total & & & & & 60 & 100 & \\
\hline \multicolumn{9}{|l|}{ Postpartum contraceptive plan } \\
\hline Permanent & & 2 & 6.7 & 4 & 13.3 & 6 & 10 & \multirow{3}{*}{0.49} \\
\hline Spacing the pregnancy & & 5 & 16.7 & 26 & 86.7 & 31 & 51.7 & \\
\hline Postpone the pregnancy & & 23 & 76.7 & 0 & 0 & 23 & 38.3 & \\
\hline & Total & & & & & 60 & 100 & \\
\hline Contraceptive Participations hi & & & & & & & & \\
\hline At least once & & 23 & 76.7 & 22 & 73.3 & 45 & 75 & 0.896 \\
\hline None & & 7 & 23.3 & 8 & 26.7 & 15 & 25 & \\
\hline & Total & & & & & 60 & 100 & \\
\hline History of Contraceptive metho & & & & & & & & \\
\hline LAPMs & & 7 & 23.3 & 4 & 13.3 & 11 & 18.3 & \\
\hline Non LAPMs & & 16 & 53.4 & 18 & 60 & 34 & 56,7 & 0,663 \\
\hline No history of contraceptives & & 7 & 23.3 & 8 & 26.7 & 15 & 25 & \\
\hline & Total & & & & & 60 & 100 & \\
\hline Reasons to withdraw contracep & & & & & & & & \\
\hline Unmet need & & 2 & 6.7 & 3 & 10 & 5 & 8.3 & \\
\hline Planning for pregnancy & & 21 & 70 & 16 & 53.3 & 37 & 61.7 & \\
\hline Side effect & & 0 & 0 & 1 & 3.3 & 1 & 1.7 & 0.618 \\
\hline Others & & 0 & 0 & 2 & 6.7 & 2 & 3.3 & \\
\hline No history of contraception & & 7 & 23.3 & 8 & 26.7 & 15 & 25 & \\
\hline & Total & & & & & 60 & 100 & \\
\hline
\end{tabular}

The Mann Whitney test resulted in a p of 0.000 $(\mathrm{p}<0.01)$ concerning the influence of media usage and peer-education on the participants' knowledge related to LAPM participation. It showed there to be a significant difference in knowledge increase between the control and treatment groups. he Mann Whitney test resulted in a p value of $0.016(\mathrm{p}<0.05)$ for the attitude difference between the control and treatment groups.

\section{DISCUSSION}

The knowledge of the pregnant mothers in the treatment group showed a statistically significant increase after the intervention which proved that the information delivered likely affected the cognitive level of the individuals (Maulana, 2009). The pretest, intervention and post-tests were conducted on the same day without recess. This did not give the participants a chance to gain knowledge from sources other than the intervention itself. It thus explained the knowledge difference that resulted from media usage and peer-education related to LAPM participation between the control and treatment groups, which proved effective. This result was also similar to that of a previous study which found there to be an increase in the participants' knowledge regarding the use of IUDs after an audiovisual intervention among women of a reproductive age (19.49\%) (Ratnawati, 2016). Despite the different media utilization, the stated findings supported the idea that better knowledge regarding contraceptive methods occurred after the media interventions. However, peer-educations 
among pregnant woman was a novelty so it cannot be compared to the other studies' results. because by giving a health lecture related to LAPMs, the participants in the intervention group became

Table 2 - Knowledge and Attitude Scores of the Control and Intervention Groups

\begin{tabular}{lcccc}
\hline & \multicolumn{2}{c}{ Intervention Group } & \multicolumn{2}{c}{ Control Group } \\
\cline { 2 - 4 } & Pre-test & Post-test & Pre-test & Post-test \\
\hline Knowledge & & & & \\
$\quad$ Mean & 58.33 & 87.08 & 70.41 & 69.16 \\
Standard deviation & 20.59 & 9.56 & 17.21 & 18.49 \\
Median & 56.25 & 87.5 & 75 & 75 \\
Mode & 37.5 & 87.5 & 75 & 75 \\
Attitude & & & 47.71 \\
Mean & 53.83 & 57 & 47.33 & 11.56 \\
Standard deviation & 6.17 & 7.30 & 11.50 & 49.37 \\
Median & 57.3 & 59.57 & 48.24 & 57.31 \\
Mode & 59.6 & 61.64 & 48.24 & \\
\hline
\end{tabular}

Another study also found there to be similar results concerning attitude difference regarding family planning programs before and after the intervention (Mahamed \& Parhkizar, 2012). An attitude difference was found in the treatment group. On the contrary, the control group showed there to be no significant difference between pre-test and post-test. Booklets have a great impact in terms of creating judgments and beliefs in individuals. Information from the media forms a cognitive foundation for attitude construction (Azwar, 2013). If such particular information experiences a strong retention inside someone's mind, then it is likely to contribute as an affective foundation for constructing judgment as part of a brand new attitude. This may result in a certain attitude towards something. In this study, this attitude is related to positive intention in terms of LAPMs participation. As the pre-test, intervention and posttest were conducted on the same day without any chances for the participants to interact with the outer world, it can be concluded that the intervention was solely responsible for the improved attitude.

A difference in the knowledge levels among the pregnant mothers regarding LAPMs was found between the control and treatment groups in this study. Another study also stated that interpersonal counseling (IPC) affected the women's knowledge related to contraceptive methods (Mahamed \& Parhkizar, 2012). Another study in Haiti showed that a peer-education intervention increased the knowledge on short-term contraceptives among women (Loh, 2015). The result of knowing something is essential to finding out the answer to particular issues. Knowledge is the result after a sensory process related to an object or issue occurs. It then constructs judgment, understanding and actions (Potter \& Perry, 2009). The stated theories and the results of this study indicate that giving a lecture paired with media usage and peer-education has a positive impact when it comes to increasing the knowledge related to LAPMs. Such a thing is possible knowledgeable which can then be reflected in their mind, increasing their knowledge. Things were different in the control group where no intervention was given. No additional lecture about LAPMs meant that there was no new knowledge.

This study also showed there to be a significant difference in attitude between the control and treatment groups. This result was supported by a previous study which also found there to be an attitude difference in treatment group after being counseled on the family planning program and contraceptive methods (Mahamed \& Parhkizar, 2012). Another study in Shanghai showed similar results after there was an intervention using booklets about health education in nulliparas. The participants' had a contraception choice postintervention, whereas previously they did not have a choice (He, et al., 2017). There are 3 main components in attitude, with the cognitive factor being one of them. The cognitive component creates ideas that are trusted and that fit with the attitude. According to Mann (1986), the cognitive factor comes from the perception and belief on what we call opinion and perception that is derived from several sources (Azwar, 2013). Compared with the theory stated by Azwar, the results of this study show that the treatment group experienced proper information retention which means that they can construct positive opinions which improve the participants' attitude. On the contrary, with no intervention given in the control group, there was no opinion created as a part of developing a particular attitude related to LAPM participation. Another factor that made the participants not support the attitude change was the fear of using LAMPs. Another study in Ethiopia showed similar results, i.e. the participants' in the study had no desire to use implants because inserting and pulling them out was a painful process (Meskele \& Mekonnen, 2014). The success of this study should not be separated from the provision of the intervention. The peer-education given by the woman who used LAMPs provided new insights for the participants. 


\section{CONCLUSION}

This study suggests that knowledge and attitude improvements can be achieved through a combination of lectures, media use and peereducation. Primary health centers are encouraged to apply this education method for better results. The longer term effects of such education need to be checked regularly in the community as knowledge levels and attitude may be affected by time as well as by other members of the community..

\section{REFERENCES}

Affandi, B. (2012). Buku Panduan Praktis Pelayanan Kontrasepsi (3 ed.). Jakarta: PT. Bina Pustaka Sarwono Prawirohardjo.

Azwar, S. (2013). Sikap Manusia: Teori dan Pengukurannya Edisi 2. Yogyakarta: Pustaka Pelajar.

BKKBN. (2016). Laporan Kinerja Instansi Pemerintah 2015. Jakarta: Badan Kependudukan dan Keluarga Berencana.

Hartanto, H. (2010). Keluarga Berencana dan Kontrasepsi Edisi 7. Jakarta: Pustaka Sinar Harapan.

He, Y., Zhang, N., Wang, J., He, N., Du, Y., Ding, J.-X., . . . Hua, K.-Q. (2017). Evaluation of two intervention models on contraceptive attitudes and behaviors among nulliparous women in Shanghai,China: a clustered randomized controlled trial. BioMed Central, 14(73), 1-11. doi: 10.1186/s12978-0170331-4.

Kemenkes RI. (2014). Pedoman Penejemen Pelayanan Keluarga Berencana. Jakarta: Direktorat jendral Bina Kesehatan Ibu dan Anak Kementrian Kesehatan RI.

Kemenkes RI. (2016). 2015 Profil Kesehatan Indonesia. Jakarta: Kementrian Kesehatan republik Indonesia.
Kemenkes, RI. (2013). Situasi Keluarga Berencana di Indonesia. Buletin Jendela Data dan Informasi Kesehatan.

Kominfo. (2014). Siapa Mau Bonus? Peluang Demografi Indonesia. Jakarta: Direktorat Jendral Informasi dan Komunikasu Publik.

Loh, H. M. (2015). Peer-Informed Learning on Increasing Contraceptive Knowledge Among Women in Rular Haiti. Pro Quest.

Mahamed, F., \& Parhkizar, S. S. (2012). Impact of Family Planning Health Education on the Knowledge and Attitude among Yasoujian Women. Global Jurnal of Health Science, 4, 110118. doi: 10.5539/gjhs.v4n2p110.

Maulana, H. (2009). Promosi Kesehatan. Jakarta: Penerbit Buku Kedokteran EGC.

Meskele, M., \& Mekonnen, W. (2014). Factors affecting women's intention to use long acting and permanent contraceptive methods in Wolaita Zone, Southern Ethiopia. Bio Med Central, 14(109), 1-9. doi: 10.1186/1472-6874-14-109.

Notoatmodjo, S. (2010). Ilmu Perilaku Kesehatan. Jakarta: Rineka Cipta.

Potter, P., \& Perry, A. (2009). Fundamental of Nursing "Fundamental Keperawatan". Jakarta: Salemba Medika.

Ratnawati, I. N. (2016). Pengaruh Pendidikan Kesehatan dengan Ceramah menggunakan Media Audiovisual terhadap Peningkatan Pengetahuan WUS dalam Pemilihan Kontrasepsi IUD Di Desa Manjung, Kecamatan Sawit, Kabupaten Boyolali. Surakarta: FKM UMS.

Shodiq, M. (2016). Faktor yang Mempengaruhi Rendahnya Kepesertaan KB Melalui Metode Kontrasepsi Jngka Panjang (MKJP) di Kabupaten Tulang Bawang Barat. Prosiding Pertemuan Ilmiah Ikatan Widyaiswara Indonesia. 